\title{
Pension reforms, risk transfer and housing finance innovations
}

\author{
K. A. Donkor-Hyiaman · E. A. Pärn² - D. Owusu-Manu³ · D. J. Edwards² (D) . \\ C. Aigbavboa ${ }^{4}$
}

Received: 18 March 2018 / Accepted: 24 July 2019 / Published online: 3 August 2019

(c) The Author(s) 2019

\begin{abstract}
Weak housing creditor protection, accentuated by weak landed property rights and underdeveloped credit information systems constitute major constraints to housing finance development in many developing countries. Improving housing creditor protection require further institutional development and financial innovation. As a trigger of financial innovation, regulation has spawned pension reforms leading to the global shift from defined benefit to defined contribution pension schemes, which has created new opportunities to improve housing creditor protection and thus engender housing finance innovations. This paper considers how pension assets-accumulated benefits and associated personal, employment and contribution information-has provided a basis for collateralized lending and an additional avenue for credit information system development. The paper proposes a pension asset-backed creditor protection model that utilizes defined contribution pension assets to improve housing credit allocation, and thus, housing finance development. Pension assets represent alternative or complementary collateral assets for securing a housing credit (mortgage). And as depositories of information, the information content of pension assets and institutions could also be used alternatively and complementarily to assess the capacity, character and contribution (equity) of potential borrowers in the credit underwriting process. Future applied research may consider how the proposed model could be integrated in existing credit underwriting systems and the operational challenges that could emerge.
\end{abstract}

Keywords Developing countries · Pension reforms $\cdot$ Housing finance innovation · Pension asset-backed housing finance $\cdot$ Pension loans $\cdot$ Pension-secured loans

\section{Introduction}

Shelter is one of the primary needs of humans and different people in different countries have satisfied this need through a variety of means. While renting is economically sensible to some people given their economic circumstances and incentives available, many people

D. J. Edwards

drdavidedwards@aol.com

Extended author information available on the last page of the article 


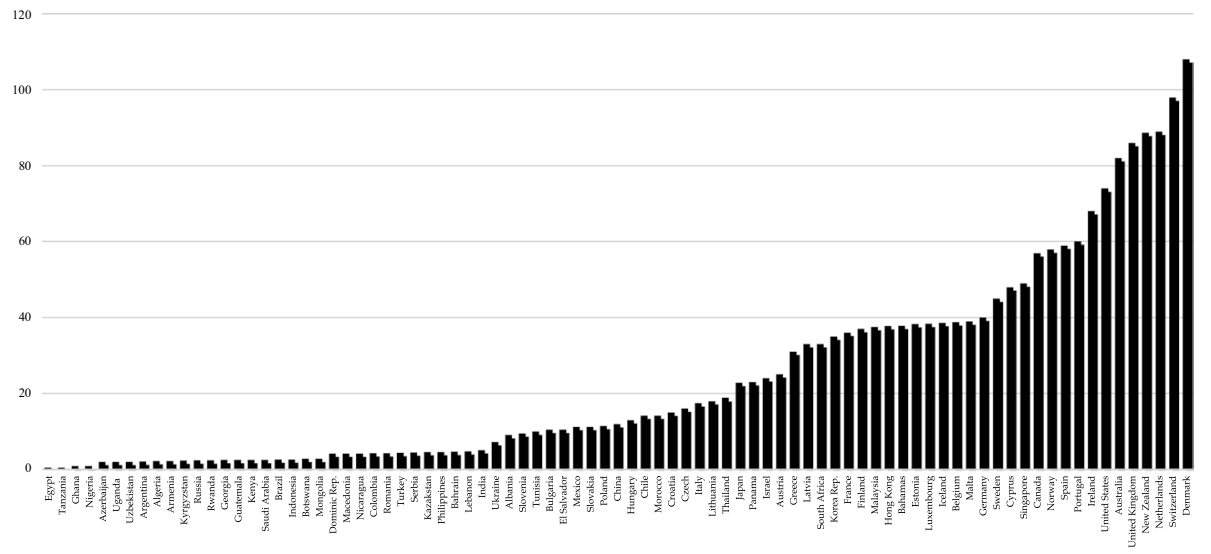

Fig. 1 Average mortgage credit/GDP ratios (\%) across countries: 2006-2010. Source: Badev et al. (2013)

across the globe prefer homeownership. A recurring concern, however, is how to finance homeownership most efficiently and effectively. Housing finance has thus become a topical issue among researchers, policymakers and international development partners. One of the lessons in development across countries is summed up in Bertrand Renaud's famous aphorism that 'cities are built the way they are financed' (Renaud 1987).

In developing countries, popular housing finance approaches include; direct government public housing; self-help incremental housing ${ }^{1}$ (see Jones and Datta 2002; Ward and Macoloo 1992; Burgess 1985, 1992; Turner 1976; Abrams 1966); housing microfinance ${ }^{2}$; pension asset-backed housing finance ${ }^{3}$ (Donkor-Hyiaman and Owusu-Manu 2016; Mutero et al. 2010), and to a lesser extent, mortgage financing (Karley 2003) as shown in Fig. 1, although believed to be the most efficient way to finance homeownership. Bible and Joiner (2009) record that mortgage market growth increased American's homeownership rate from 64 to 69\% between 1993 and 2005. Over the same period, homeownership among

\footnotetext{
1 Owners become self-developers relying on small crafts and trades to build 'gradually' over 5-15 years using their 'sweat equity' (personal savings) accumulated over long periods (Mathema 1999; Tomlinson 2007) or as and when funds become available (Donkor-Hyiaman and Owusu-Manu 2016; Derban et al. 2002).

${ }^{2}$ In this approach, small and short-term unsecured loans are mixed with sweat equity in the incremental housing process. Informal moneylenders and informal savings and loans associations like the susu groups in Ghana; tanda in Mexico; hui in Vietnam; chilimba in Zambia; paluwagon in the Philippines; gamaiyah in Egypt; kusukus in Ethiopia are the main sources of these loans (Anzorena et al. 1998; Ferguson 1999; Mitlin 1997; Patel 1999; Siembieda and López Moreno 1999; Paulson and McAndrews 1998; Bouman 1995; Johnson and Rogaly 1997; Merrett and Russell 1994; O'Reilly 1996).

3 Pension asset-backed housing finance comes in two forms; pension loans and pension-secured (backed) loans (Sing 2009). The pension loan are direct loans from the fund secured in two ways: over the member's ring-fenced accrued benefits in a DC scheme or effectively as a mortgage loan in favour of the fund over the property in question (Short et al. 2009). Pension-secured loans on the other hand are designed to enable potential borrowers to collateralise their accumulated pension equity as security for a housing loan from a third party, mostly commercial banks (ibid). Pension-secured loans are popular in Brazil, Mexico, Singapore, South Africa, Botswana, Namibia, Zambia and Mauritius (Donkor-Hyiaman and Owusu-Manu 2016; Afrane et al. 2016; Phang 2007; McCarthy et al. 2002; Addae-Dapaah and Leong 1996).
} 
low-income households and the first-time homebuyers market, in particular, increased by 12 million due to growth in sub-prime mortgage lending (Gramlich 2007).

Despite its potential contribution to economic development (Asabere, McGowan and Lee 2016; Dickerson 2009; Renaud 2008; Jaffee 1999) by accelerating access to homeownership (Gevorgyan et al. 2006), mortgage lending in developing economies is limited inter alia by both the underdeveloped nature of credit information systems and pervasive collateral risk (De Soto 2001). The lack of credit information makes it difficult for lenders to conduct credit analysis adequately and hence exposes lenders to a high chance of lending to people who lack the capacity and or have the willingness to service their mortgage obligations. Theoretically, this situation will often restrict lending or discourage lending at all (Stiglitz and Weiss 1981).

To promote lending in a world of imperfect information between lenders and borrowers, collateral is needed. Indeed, Scholars have shown that safer borrowers within an observationally identical risk pool pledge more collateral (Bester 1985; Chan and Kanatas 1985; Besanko and Thakor 1987) thus improving their incentives to work hard to reduce their likelihood of default (Chan and Thakor 1987; Boot and Anjan Thakor 1994). Beyond pledging collateral per se, lenders are more willing to extend credit when they have more power to protect themselves ex-post by easily forcing repayment or capturing the collateral in case of default through strong property rights (Townsend 1979; Aghion and Bolton 1992; Hart and Moore 1994, 1998). Therefore, credit information and collateral with its associated property rights are substitutes in credit screening and creditor protection (Brown et al. 2009).

Despite land registration reforms in many developing countries particularly in Africa, private property rights protection is still weak due to inefficient legal systems and unresolved complexities of land tenure (cf. Toulmin 2008). Toulmin (2008) reveals that only $2-3 \%$ of the land is held by written title in West Africa, mainly in a few major cities. Land in Africa is also largely communally held, thus creating two main problems. First, borrowers cannot pledge land they do not own as collateral for credit. According to Ollennu (1962):

Land belongs to a vast family of which many are dead, few are living and countless numbers are still to come. (Ollennu 1962: p. 4)

Where communal lands are pledged, lenders often cannot register mortgages against them (Toulmin 2008). Where registration is possible, it is often overly bureaucratic and costly. For example, Burkina Faso recorded the highest cost of mortgage registration and title transfer at $12 \%$ of property value whilst Rwanda recorded the longest registration time (1 year) globally (Butler et al. 2009). Inefficient legal systems in most developing countries render mortgage foreclosure risky and unviable. In Ghana, lenders require almost 2 years (i.e. 706 days) to foreclose collaterals in default (ibid). Therefore, when liens are unenforceable, the difference between mortgage loans and unsecured debt is marginal (Chiquier et al. 2004).

Besides, Africa's urbanisation is characterised by slums and backyard houses due to poor urban planning and substandard housing units that are poorly maintained and/or developed using substandard building materials. This feature exposes lenders to collateral risk (Karley 2002, 2003). Therefore, weak legal systems, inefficient foreclosure processes and substandard collateral nullifies the benefit of real property collateral as a solution to credit information risks in mortgage lending ex post.

The need for alternative collateral assets has become rife. The UN-Habitat (2012) in a review of the housing profile of Ghana suggested that introducing a: "new regulatory 
framework to enable alternative forms of collateral would benefit housing financing" (p. 26). Given the shift from defined benefit to defined contribution pension schemes, which ring-fences the contributions of each pension member and thus offers clear private property rights, pension assets have emerged as alternative collateral assets for housing finance. Jones and Datta (2002) suggest that deregulation and reforms have spawned innovation and a wider interpretation of the concept of collateral. In effect, innovation of new arrangements will alter the way that lenders and borrowers interact (Bodie 1990).

Pension asset-backed housing finance has thus become popular in recent times in many countries including Brazil, Mexico, South Africa Botswana, Namibia, Kenya, Zambia and Mauritius (Donkor-Hyiaman and Owusu-Manu 2016). In spite of this innovation in housing finance enabling the collateralization of pension assets as an alternative to real property collaterals for mortgages, lenders still face an arduous challenge in assessing the creditworthiness of potential homeowners. This challenge is due to the underdeveloped nature of credit information systems. This may be due to a cultural aversion to debt (Teye et al. 2015) and the high level of financial exclusion ${ }^{4}$ in Africa in particular and thus the unfamiliarity of many Africans with formal credit and its obligations (Karley 2003). Therefore, private credit information systems such as credit bureaus are unviable and are unlikely to emerge (Pagano and Jappelli 1993).

The need for alternative information sources for the development of credit information systems to enable the establishment of the creditworthiness of potential borrowers is thus increasing. This study therefore develops a model that proposes the use of pension fund data for credit assessment. This is based on the idea that some of the information requirements for credit assessment can be obtained from pension funds. Credit assessment based on the five Cs lending criteria, i.e. capacity, character, capital, collateral, and condition is quite standard in the credit market (Karley 2002). Four of these parameters, i.e. capacity, character, capital, collateral could be assessed from pension fund data as will be shown later.

The rest of the paper is structured as follows. Immediately following this section is a discussion of the research approach, followed by a discussion of the potential of pension assets in relation to the five Cs lending criteria. This is followed by a presentation of the proposed model.

\section{Research approach}

The design of the Pension Asset-Backed Creditor Protection Model is informed by the concept of financial innovation entwined with the creative and imaginative theory of conceptualization (CITC). CITC is based on an 'openness to change' psychology-that is, the extent to which an individual is imaginative, inquisitive and refined (Egan 2005). Consequently, the creative and imaginative behaviors of the authors underpin the conception of the conceptual model and its scientific jurisdiction (Zhou 2003). An iterative research approach adopted for this paper draws upon three core aspects, namely: (1) a critical literature review of relevant pension asset-backed housing finance models and schemes to

\footnotetext{
4 The World Bank Global Financial Development Indicators for example, illustrate that: there are only 15 bank accounts for every 100 adults in the median African country, while there are 42 outside Africa; and there are 3.1 branches per 100,000 adults in Africa, while there are 9.6 outside Africa. In Ghana, Boamah (2011) notes that only $10 \%$ of the bankable population has bank accounts.
} 
identify the various ways through which pension fund capitalism has engendered housing finance innovations globally; (2) the creative and imaginative theory of conceptualization (Collins and Cooke 2011; Egan 2005); and (3) the concept of financial innovation (Lerner and Tufano 2011; Miller 1986).

The Organisation for Economic Co-operation and Development (OECD 2005) define innovation in modern industries as a process of adopting new approaches to design and business models. Ramadani and Gerguri (2010) concur with this aforementioned definition and add that innovation represents an activity of creating new, or enhancing existing products or services, technological process and organizations. This process is the instrument of entrepreneurship - the act that endows resources with a new capacity to generate wealth (Drucker 1998). Wealth is an output of innovation, which results in a higher level of economic welfare and is the essence of economic growth (Engelen et al. 2008). Miller (1986) defines financial innovation as something that produces economic growth in excess of what would otherwise occur. This includes the act of creating and then popularising new financial instruments as well as new financial technologies, institutions and markets (Lerner and Tufano 2011). This functional characterization of financial innovation gives rise to classification of types, which according to Schrieder and Heidhues (1995) is useful in three distinctions: (1) financial system/institutional innovation-which relates to changes in business structures, to establish new types of financial intermediaries, or to change the legal and supervisory framework which can affect the financial sector as a whole (Engelen et al. 2008). Important examples include formalizing informal finance systems, or setting up a completely new service structure; (2) process innovation-which relates to the introduction of new business processes leading to increased efficiency, and market expansion (cf. Fagerberg 2003); and (3) product innovation - which relates to the introduction of new products or services including new credit, i.e. adjustable-rate mortgages, home equity loans, variable rate bonds, zero-coupon bonds and hire purchase, which are created to meet market needs - client-focused (Bátiz-Lazo and Woldensebet 2006). Product innovations are introduced to respond better to changes in market demand by filling a gap in the products and services available to customers or to improve the efficiency of supply (Schrieder and Heidhues 1995).

Previous discussions on the triggers of financial innovation are little more than a listing of factors, which include: regulations and taxes; computer and technological advances; and finance theory (Miller 1986; Merton 1995). Tufano (2003) notes that market problems inter alia constitute the dominant idea that creates the impulse to innovate as an optimal response. These market problems include incomplete markets, agency concerns and information asymmetries (ibid). This perception is an apolitical and mechanical view focused on solving what are essentially technical problems of markets around the issues of information and pricing. The benefits of financial innovation permeate throughout society and include enhancing the sustainability of institutions and their outreach to the poor (Schrieder and Heidhues 1995). According to Engelen et al. (2008), financial innovation is a powerful and convenient metaphor for progress which secures real social benefits that facilitate risk dispersion and pooling through the financial system. This improves the allocation of capital, creation of liquidity and democratises the availability of credit, thus making market pricing and risk more accurate, easily manageable and welfare enhancing for lenders, borrowers and the general economy (Bernanke 2007). Innovations can increase the availability of credit to households and corporations' through greater provision of financial products (Hamilton et al. 2007). Financial innovation is therefore fundamental for promoting good economic performance (Lipsky 2007) and engendering social equality through equitable access to finance for home ownership (Blundell-Wignall 2007, p. 2). 


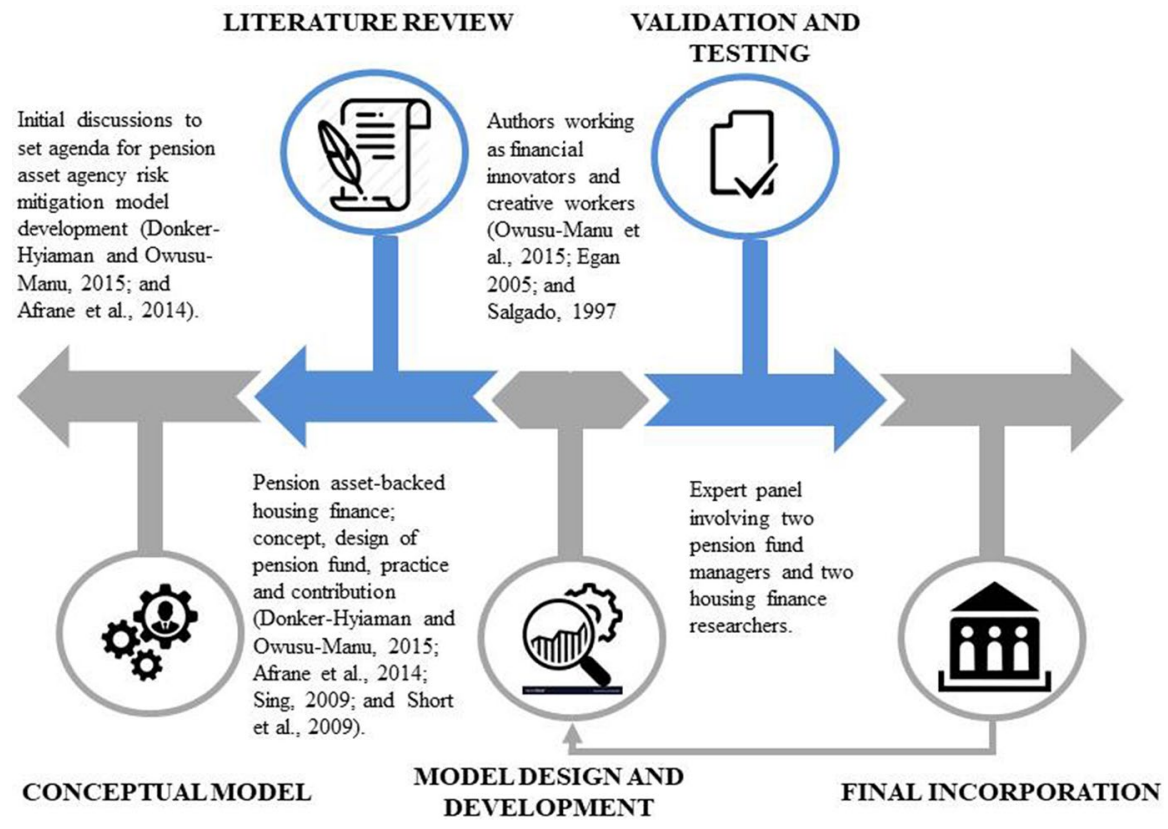

Fig. 2 Design process of the pension asset-backed risk mitigation model

\subsection{The model design and development process}

Five inextricably linked processes were involved in the design and development of the conceptual model (see Fig. 2). First, initial discussions were held with other academics and industry practitioners to develop the concept proposal (see Donkor-Hyiaman and Owusu-Manu 2016; Afrane et al. 2014). Second, a critical review of extant literature on pension asset-backed housing finance commenced with a specific focus on the concept, design of pension funds and practice (Sing 2009; Short et al. 2009; Rakodi 1995; Reddy and Brijlal 1992; Karley 2003). This process identified two main channels (collateral and information) through which pension assets could be useful in mitigating lending risk in mortgage lending. Third, the model was designed and developed through assimilating three dimensions of financial innovation (i.e. product, process and institutional) via CITC.

Fourth, robust validation and testing of the conceptual model was achieved through independent peer reviews obtained from two pension fund management practitioners and two housing finance researchers. This review specifically sought to identify the model's practical and theoretical challenges. A practical issue identified during this stage of the process is the likelihood that an individual's accumulated pension may be insufficient to collateralize for a housing loan. A potential remedy is offered via cross or co-collateralization which involves third parties (such as family and friends) either on a commercial or mutual basis, lending collateral to potential borrowers. This could resolve the theoretical problem of using the same pension assets and subsequent contributions for collateral and loan repayment. In this case, new pension fund members or non-members could borrow collateral to secure a housing loan. 


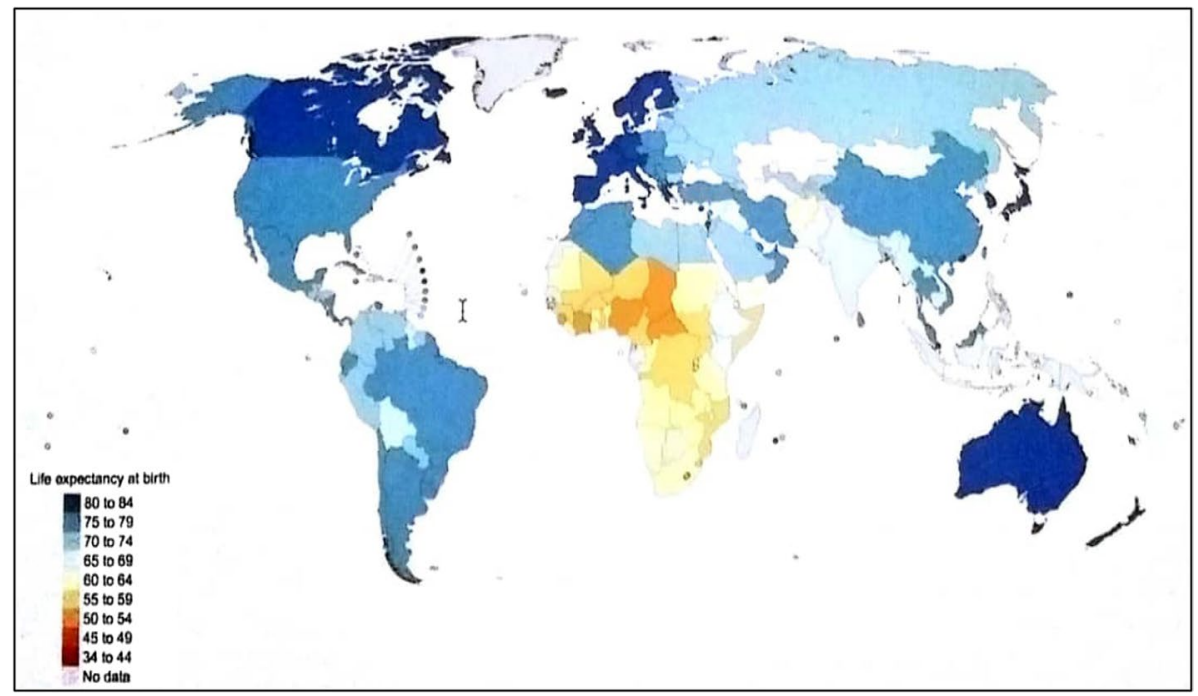

Fig. 3 Average life expectancy at birth for the world reached 71.4 years in 2015. Source: United Nations (2017)

\section{Credit analysis, risk mitigation and creditor protection: what have pension assets wrought?}

For lending to take place, financial institutions would generally want to establish that basic requirements are met. These requirements relate to the circumstances of the potential borrower, property, and the environment in which lending occurs. These requirements could be classified as the five Cs lending criteria-capacity, character, capital, collateral, and condition. Although other requirements may be fulfilled, lenders often ensure that these basic requirements are met.

Before delving into how pension assets could play a role in credit assessments, it is imperative to understand the basis for pension asset-backed housing finance. Pensions are deferred incomes receivable upon retirement, except where legislation allows members to utilize pension savings to meet other composite needs, including health, education and housing before retirement (Sing 2009; Holzmann et al. 2005; Bodie 1990). However, the United Nations Development Programme Human Development Report (2014) raise a concern that most African's do not attain the pensionable age of 65 years to enjoy their pensions in retirement, as shown in Fig. 3. The average life expectancy across Sub-Saharan Africa is a mere 54.9 years. At a country level, life expectancy in Ghana, Kenya and Cameroon is 64.6, 57.5 and 52.1 years respectively (ibid). Recently, the United Nation Children's Fund [UNICEF] (2014) estimated that the average African life expectancy of 58 years is about 12 years less than the global average. Investing substantially in pensions that may not be redeemed raises serious questions about the purpose, use and value of pension funds in Africa. Some commenters opine that pension funds are a foreign ideal and incongruent with basic welfare needs of people living in developing countries. Sing (2009) for example argues that: 
Prudent regulation emphasises the need to preserve retirement savings for fund members' old age. However, what is the use of being assured of a comfortable retirement without a roof over one's head today? (p. 68).

Pension assets could therefore play a role in the development of housing finance in Africa as discussed below.

\subsection{Capital}

Capital in mortgage credit analysis is the equity contribution a potential borrower makes towards a mortgage. This is often accumulated through savings. Pension funds are savings and investment schemes. Their investment in housing take two main forms: (1) enduser models, and (2) investment models (Short et al. 2009). The investment model involves direct housing development while end-user models, which is the focus of this section, assist a pension fund member to obtain housing capital for home purchase or construction (Donkor-Hyiaman and Owusu-Manu 2016). This type of housing finance may be in form of pension loans and pension-backed loans (Sing 2009), collectively called pension asset-backed housing finance (Donkor-Hyiaman and Owusu-Manu 2016). Administered internally by the pension fund or through a designated administrator, pension loans enable members of pension funds to borrow their accumulated pensions capital as a mortgage (Short et al. 2009). Where the accumulated pension capital is inadequate for the purchase of a house, it could serve as an equity contribution or down payment for a mortgage (Donkor-Hyiaman and Owusu-Manu 2016). Pension loans are common in Singapore, Mexico, Brazil, South Africa, Zambia and Uganda as shown in Table 1.

\subsection{Collateral}

Mortgage finance is secured against the value of the purchased property. Lenders estimate the viability of repossession on default and whether the property can be sold to repay the loan. Suitability of the property is assessed on the basis of its legal status, location, structure and market value (Karley 2002). Land tenure problems in many developing countries make it difficult to use real property as collateral. Pension assets have thus been used in many countries as alternative collateral to support housing finance. Pension-secured loans are designed to enable potential borrowers to collateralise their accumulated pension equity as security for a housing loan from a third party, mostly commercial banks (Short et al. 2009). These are permitted in Brazil, Mexico, South Africa Botswana, Namibia, Zambia and Mauritius. For example, the Central Provident Fund (CPF) and INFONAVIT (Castillo and Laviada 1999) in Singapore and Mexico respectively are multi-pillar defined contribution (DC) scheme which allows members to use their accrued pension benefits in the 'ordinary account' for housing purposes. In Ghana, Section 103(2) of the National Pension Act, 2008 (Act 766) allows for pension-secured loans (Afrane et al. 2014; Donkor-Hyiaman and Owusu-Manu 2016).

Pension-secured loans work best in DC pension schemes, which ring-fences members' account, and thus ensures that a default in loan repayment does not affect other members of the pension fund. Table 1 notably illustrates that most of the pension asset-backed housing finance models are associated with DC schemes, with the exception of Namibia, Tanzania, Kenya and Zambia, where DB schemes are also linked to pension asset-backed housing finance. In DC pension schemes, accrued pension assets are based on the amounts credited 


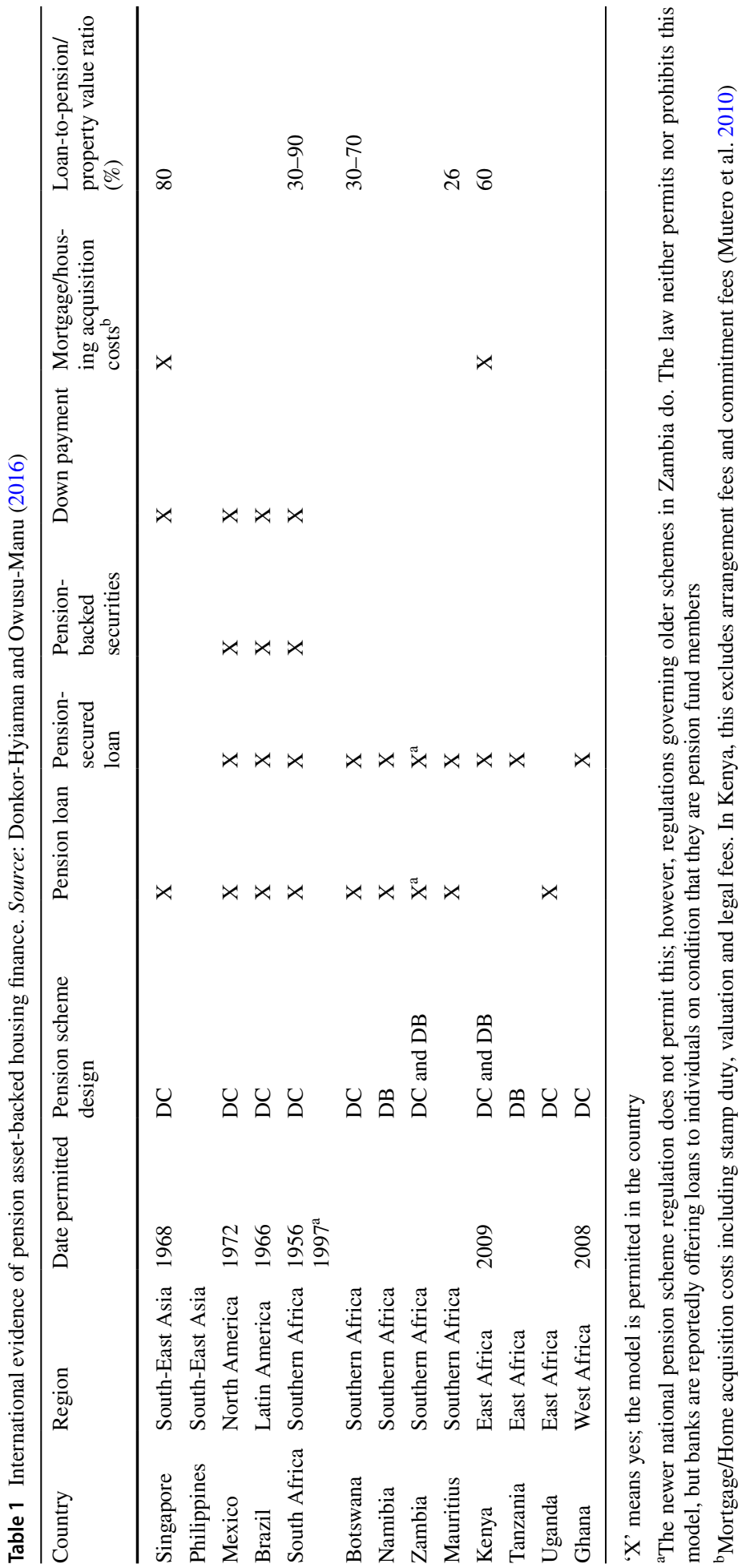


to members' accounts (through employer contributions and if applicable, employee contributions) plus any investment returns. Ownership is clearly defined, which enhances the chances of effectively foreclosing on pension asset collaterals upon loan default ceteris paribus. For instance, the opportunity to collateralize pension assets as against tying the loan to a house (as security) relieved lenders of the arduous circumstance and time involved in evicting borrowers upon default in South Africa. In this case, the outstanding loan amount is deducted from defaulting borrowers' accrued pension benefits.

Liquidity is enhanced via the capital market. This benefits pricing as pension-secured loans are cheaper than micro-finance, unsecured finance and mortgage-secured bank lending in South Africa. According to Sing (2009), the interest rate of 'prime rate 1\%' for the average pension-secured loan, was found to be cheaper than mortgage lending (at prime rate) and significantly cheaper than unsecured lend (prime $+5 \%$ ). However, in Uganda, although no interest is charged on the loan, the scheme retains $1 \%$ of the loan amount to service the cost of land title verification and to meet monitoring costs of ensuring that loans are used for housing, which is an issue in South Africa (Sing 2009).

Pension-secured loans have contributed considerably to housing finance development. In Brazil and Mexico, the Fundo de Garantia por Tempo de Serviço (FGTS), and the Institute Nacional del Fondo de Vivienda para los Trabajadores (INFONAVIT) and Fondo de Vivienda del Institute de Seguridad y de Servicios para los Trabajadores del Estado (FOVISSSTE) respectively are the biggest savings institutions that serve mainly lowincome households and have supplied circa 3.631 million (through the Caixa Economica Federal (CEF) according to UN-Habitat 2010) and 3.5 million housing units (International Monetary Fund 2007). The CEF and INFONAVIT and FOVISSSTE account for over $55-60 \%$ of housing finance (or mortgage market portfolio) in Brazil and Mexico respectively (Herbert et al. 2012; International Monetary Fund 2007). This is equivalent to about 93.6\% of funds held by INFONAVIT and FOVISSSTE (UN-Habitat 2010).

Between 1970 and 2008, the Housing Development Board's (HDB) pension loans-tototal housing loans averaged about 58\% in Singapore (cf. McCarthy et al. 2002). Accordingly, pension-secured loans contributed to the increase in homeownership from $26 \%$ in 1970 to about $90 \%$ in the 1990s (Phang 2007). Addae-Dapaah and Leong (1996) note that pension contributions are more than enough to meet monthly repayments of an average purchaser. In South Africa, pension-secured loans and pension loans amounted to about R17 billion (£1.1127 billion) as at 2009 (Sing 2009). According to the Centre for Affordable Housing Finance in Africa, there are about 850,000 outstanding pension-backed loans, based on average loan size of about R20,000.

\subsection{Capacity}

A borrower's financial ability is critical in the credit analysis process. Capacity is usually assessed using the ratio that expresses the percentage of an applicant's income needed to cover monthly debt obligations, including the mortgage repayments - the house-debt-toincome ratio (Karley 2002). This assessment requires household income and expenditure data, which for many people in developing economies, characterised by large informality may be difficult to obtain. The available data may also be scanty and unreliable because of the difficulty in verifying it. Problems with access to income data of pension fund members may be solved since the pension contribution is often a percentage of their incomes. In other words, the size of a contributor's income over time could be estimated by dividing the amount contributed monthly by the contribution rate. This estimation could be done 
to provide insight into the distribution of members' reported income and changes in their capacity over time.

\subsection{Character}

Character referencing is a major constrain to mortgage loan underwriting and risk-based pricing in developing economies due to a paucity of credit information systems (such as private credit bureaus). In developed countries, lenders use credit reports generated from credit performance data sourced from financial institutions by private credit bureaus and public credit registers to assess the character of borrowers. This information provides a proxy for estimating the willingness and probability of potential borrowers to service their debts. However, high levels of financial exclusion and debt aversion in some African developing economies (Teye et al. 2015) means that the volume of data may be small with low mobile pools of borrowers and high costs of exchanging information-a situation that cumulatively impedes the emergence of credit information systems (Jappelli and Pagano 1993). Credit bureaus are relatively new institutions in Africa with limited access to the market. However, existing institutions such as pension schemes are depositories of information that might be useful character proxies for loan underwriting purposes. At least, three categories of information about prospective borrowers could be extracted from pension funds-namely, personal information, employment information and pension contribution performance information.

\subsubsection{Personal and employment information}

In Ghana for example, the Social Security and National Insurance Trust's (SSNIT) membership form and the address details form collects bio-data information via four main sections completed by the applicant. Sections one, two and three collect information of: the name of the applicant; names of applicant's parents respectively; and the current mailing address (including information on applicant's postal address, email address, mobile and telephone numbers, region of residence). Section four collects information of the applicant's residential address including house number, building name, street name, city, location and region. Moreover, apart from other bio-data (such as the age, sex, date of birth, marital status, number of children), the membership form also collects employment details. This includes name of employer, industry by implication, position at work and income. This information is useful to creditors for loan application screening purposes.

\subsubsection{Pension contribution performance information}

Credit reports often include a summary of information such as the number and type of accounts that are past due or in good standing, and detailed accounts information related to high balances and the date accounts were opened. In Ghana for instance, pension contributions into the first and second tier pension schemes are liabilities (debt) to both employers and employees but the employer is obliged to remit the contributions to the SSNIT and the private pension fund managers respectively. This fiscal obligation reveals information about the character of prospective loan applicants which could be utilized in creditworthiness assessments.

Figure 4 illustrates some of the useful information content that could be generated from the distribution to pension contribution remittances as a proxy for character referencing 


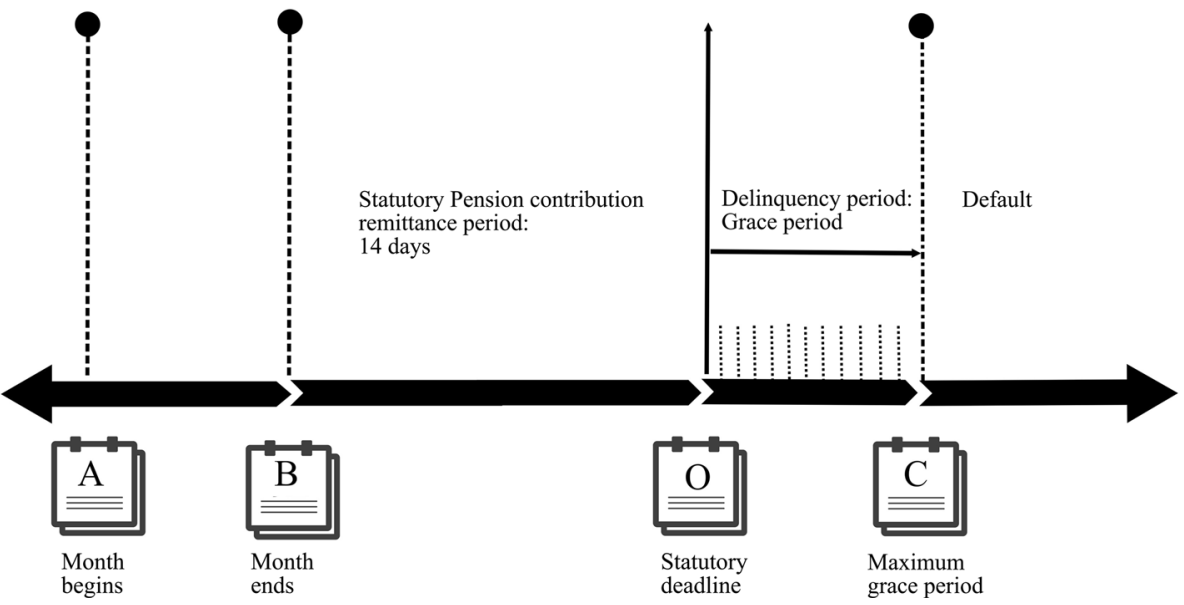

Fig. 4 Pension contribution remittance schedule

and thus vital for loan underwriting. Points $\mathrm{A}$ and $\mathrm{B}$ represent the beginning and end of each month respectively. The distance $B-O$ is the 14-day period after the end of a month within which pension contributions are to be remitted to the approved pension fund manager by statute. That means that remittances after this period are in default. In finance theory, default is failure to meet the legal obligations (or conditions) of a loan (O'Sullivan and Sheffrin 2003). However, there might be some delays in practice, which may be out of the control of the borrower like delays in payment of salaries. Thus, the default period can be separated into two. The first we shall call a grace period, labelled $O-C$, which may also be referred to as the delinquency period or technical default period accounts for such practical delays. In this vein, Krainer and Laderman (2011) notes that the mortgage delinquency rate was defined to be loans past-due 60 days or more, plus foreclosures between 1980 and 2005, in the United States.

Conversely, in the Mortgage Encyclopaedia, Guttentag (2004) defines a delinquency as a mortgage payment that is more than 30 days late. Payments not received after point $C$ are in actual default. The information content of the distance from $B$ and beyond could be used to generate an aging schedule. That is, an accounting table that shows the relationship between a company's or a person's bills and invoices and its due dates-for both accounts payable and accounts receivable to help determine whether pension fund members and their employers are current on their pension contribution remittances and whether they are paying it on time. Based on the distribution of pension contribution remittances, default probabilities could be estimated and utilized as a proxy for a potential borrower's character, as well as the factors that might be driving default for purposes of loan underwriting. In essence, information from the pension scheme setup has adverse selection and moral hazard mitigation effects that may enhance credit allocation and reduce credit rationing in developing countries where credit information systems have not emerged. 


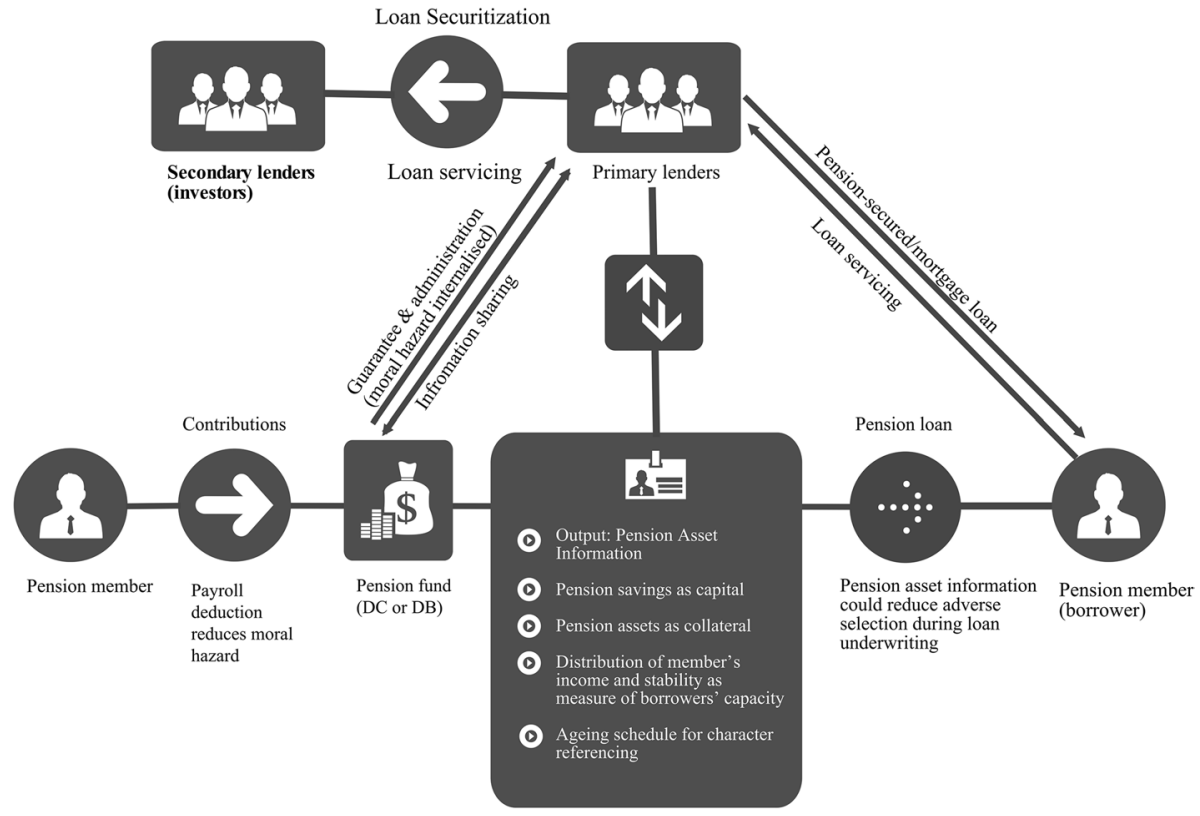

Fig. 5 Pension asset-backed risk mitigation model

\section{Integrating pension assets into mortgage underwriting: pension asset-backed creditor protection model}

Figure 5 presents a conceptual framework through which pension asset could be innovatively used to mitigate lending risks and promote housing finance development. The model consists of four agents: (1) pension fund member; (2) pension fund; (3) primary lenders; and (4) secondary lenders. The pension fund member makes monthly contributions to the pension fund to accumulate benefits over time. The pension loan model enables a member to borrow his or her accumulated pension benefits for housing purposes. Alternatively, the pension-secured loan model, allows the member to post their accumulated benefits as collateral often to a third party (primary lender) — financial institution-such as a bank for a mortgage. The primary lender could enhance its liquidity position and reduce its risk by selling the pension-secured loans on its balance sheet to a secondary lender-including institutional investors such as insurance firms and pension funds. To mitigate adverse selection ex ante when there is limited information on prospective borrowers (who are also members of the pension fund) due to the lack of formal credit information systems, the lenders in the model (i.e. pension fund and banks) could use the pension assets to assess the creditworthiness of the borrower and thus screen the loan application.

Since pension assets provide partial information about a borrower, lenders cannot make a perfect prediction of a borrower's behaviour after advancing the loan, hence they must also mitigate the consequences of default (moral hazard) when the property to be purchased is not mortgageable. Often, this is due to land titling and property rights problems in most developing economies. The accumulated pension benefits of the borrower could then be pledged to the lender as security for the loan, in order to internalize 
possible moral hazards. Indeed, moral hazard models developed using collateral theory indicate that posting collateral improves borrowers' incentives to work hard, thus reducing their likelihood of default (Chan and Thakor 1987; Boot and Anjan Thakor 1994). This effort could be maximized particularly in view of the possibility of a borrower losing their pension benefits in the event of default. Additionally, the posting of accumulated pension benefits as collateral could also signal borrower quality ex ante when it is difficult to distinguish potential borrowers. Adverse selection models predict that safer borrowers within an observationally identical risk pool pledge more collateral (Chan and Kanatas 1985).

Given the low levels of income in Africa at large, individual pension asset values may be low and therefore provide partial security to lenders when collateralized for a mortgage. Although a challenge, it could open new vistas of innovations. For example, opportunities for co-collateralization could emerge where borrowers with inadequate accumulated benefits could borrow at a fee, the accumulated benefits of other pension fund members. Alternatively, opportunities for cross-collateralization may be possible-when the collateral for one loan is also used as collateral for another loan.

Besides using pension assets as collaterals and alternative character referencing technology, the pension contribution rate (in terms of size and frequency) is linked to the size and stability of income as well as the security of employment - these indicators are useful for assessing the capacity of potential borrowers to repay a loan. In addition, pension savings could form a vital equity contribution (down payment) for a mortgage. Low levels of income coupled with a high cost of living in most developing countries severely constrains household savings. Studies in South Africa and Ghana note the general lack of savings to fulfil the initial deposit requirement for mortgages (Karley 2002, 2003). However, Edwards (1995) notes that, sophisticated financial products like pension asset-backed housing finance have increased the rate of savings. Likewise, Morandé (1998) found that funded pension funds increased savings in Chile which improved the ability of pension fund members to raise down payments for a mortgage.

Moreover, deferred liabilities of pension funds mean they usually have long-term investible funds that match the long-term (usually about 20-30 years) capital needs of housing finance (Afrane et al. 2014; Sing 2009). This characteristic of pension funds is vital for eliminating the maturity gap problem created by the prevalent use of short-term funds in financing long-term housing assets. Therefore, the asset-liability matching characteristics of pension funds could reduce liquidity risk and liquidity risk premium, and in turn result in low interest rates (Afrane et al. 2014). This relationship could have the effect of lowering loan repayment amounts, improve affordability and expand housing finance opportunities (Chiquier and Lea 2009). Coupled with guarantees that are typically provided by the pension schemes, the average pension asset-backed housing loan is likely to be cheaper than a conventional mortgage, as is the case in South Africa (Sing 2009).

Further, payroll deduction is often a feature of mandatory pension schemes; for example, the first tier and second tier pension scheme in Ghana. Where pension contributions are to be used as housing loan repayment, the payroll deduction mechanism could be useful in mitigating moral hazards; i.e. loan defaults. Payroll deduction of pension-secured loan repayments removes borrowers' unwillingness to service their debt compared to the case where loan payments are not deducted as source. Since pension asset-backed housing loan payments are payroll deducted (i.e. in South Africa), an aspect of loan delinquency and default depends on employers' characteristics. However, ceteris paribus payroll deduction should lower default risk to the advantage of both lenders and borrowers. While investment losses to lenders may be reduced, potential borrowers may benefit in terms of lower default 
risk premiums that will result in lower interest rates, lower repayments and an improvement in affordability.

\section{Conclusion}

Well-developed housing finance systems and institutions promote housing market development. Most developing economies are however plagued with weak legal and information institutions beside other problems. For instance, land administration inefficiencies have rendered most lands unregistered, putting land title and ownership at risk, thereby increasing collateral risk. High financial exclusion on the other hand has rendered formal credit information systems underdeveloped and non-existent in some countries. Most potential borrowers are therefore credit rationed because lenders cannot distinguish between good and bad borrowers. In effect, formal housing finance and housing markets remain underdeveloped. Nevertheless, regulation has spawned pension reforms - the move from DB pension schemes to DC pensions Schemes-that has expanded the set of assets that can be collateralize for a mortgage and created new opportunities for credit information referencing and screening.

Based on the concept of financial innovation interlinked with the creative and imaginative theory of conceptualization, this paper develops a conceptual model - the pension asset-backed lending risk mitigation model — that utilizes pension assets-accumulated benefits and associated information - to reduce adverse selection and moral hazards in mortgage lending. Pension-secured loans for instance enable the collateralization of pension assets as security for housing finance, which is a major source of housing finance in Singapore, Brazil, Mexico and emerging in some African countries including South Africa, Kenya, Tanzania and Ghana. The information content of pension assets such as the personal and employment data as well as the distribution of pension contributions could be used to predict the character of potential borrowers. This proposed mechanism could thus serve as alternative or complementary credit referencing mechanisms in countries like Ghana where traditional private credit bureaus have not emerged on a significant scale. Further studies could look into the practical challenges in operationalizing the pension asset-backed creditor protection model.

Open Access This article is distributed under the terms of the Creative Commons Attribution 4.0 International License (http://creativecommons.org/licenses/by/4.0/), which permits unrestricted use, distribution, and reproduction in any medium, provided you give appropriate credit to the original author(s) and the source, provide a link to the Creative Commons license, and indicate if changes were made.

\section{References}

Abrams, C. (1966) Squatter settlements: The problem and the opportunity. Office of International Affairs, Department of Housing and Urban Development, No. 63.

Addae-Dapaah, K., \& Leong, K. M. (1996). Housing finance for the ageing Singapore population: The potential of the home equity conversion scheme. Habitat International, 20(1), 109-120.

Afrane, S. K., Owusu-Manu, D., \& Donkor-Hyiaman, K. A. (2014). Towards innovative housing financing in Ghana: An evidence-based from South Africa's pension housing financing system. Public Policy and Administration Research, 4(4), 97-110.

Aghion, P., \& Bolton, P. (1992). An incomplete contracts approach to financial contracting. The review of economic Studies, 59(3), 473-494. 
Anzorena, J., Bolnick, J., Boonyabancha, S., Cabannes, Y., Hardoy, A., Hasan, A., et al. (1998). Reducing urban poverty; some lessons from experience. Environment and Urbanization, 10(1), 167-186.

Asabere, P. K., McGowan, C. B., Jr., \& Lee, S. M. (2016). A study into the links between mortgage financing and economic development in Africa. International Journal of Housing Markets and Analysis, 9(1), 2-19.

Badev, A. I., Beck, T., Vado, L., \& Walley, S. C. (2013). Housing finance across countries: New data and analysis. World bank policy researchworking paper 6756. http://econ.worldbank.org. Accessed 20 Dec 2015

Bátiz-Lazo, B., \& Woldensebet, K. (2006). The dynamics of product and process innovation in UK banking. Journal of Financial Services Management, 1(4), 400-421.

Bernanke, B. (2007). Regulation and innovation, speech to the Federal Reserve Bank of Atlanta's 2007 financial markets conference, May 15th 2007. http://www.federalreserve.gov/newsevents/speech/berna nke20070515a.htm. Accessed October, 2016.

Besanko, D., \& Thakor, A. V. (1987). Collateral and rationing: Sorting equilibria in monopolistic and competitive credit markets. International Economic Review, 28(1), 671-689.

Bester, H. (1985). Screening vs. rationing in credit markets with imperfect information. American Economic Review, 75(4), 850-855.

Bible, D. S., \& Joiner, G. (2009). Adjustable rate mortgages and the mortgage crisis. Property Management, 27(3), 152-162.

Blundell-Wignall, A. (2007). Structured products. Financial Market Trends, 2007(2), $27-57$.

Boamah, N. A. (2011). The regulatory environment and housing finance market in Ghana. Property Management, 29(5), 406-422.

Bodie, Z. (1990). Pensions as retirement income insurance. Journal of Economic Literature, 38, 28-49.

Boot, A., \& Anjan Thakor, A. (1994). Moral hazard and secured lending in an infinitely repeated credit market game. International Economic Review, 35(4), 899-920.

Bouman, F. J. (1995). Rotating and accumulating savings and credit associations: A development perspective. World Development, 23(3), 371-384.

Brown, M., Jappelli, T., \& Pagano, M. (2009). Information sharing and credit: Firm-level evidence from transition countries. Journal of Financial Intermediation, 18(2), 151-172.

Burgess, R. (1985). The limits of state self-help housing programmes. Development and change, 16(2), 271-312.

Burgess, R. (1992) Helping some to help themselves: Third world housing policies and development strategies. In Beyond Self-Help Housing (pp. 75-91). London: Mansell Publishing.

Butler, S., Kravkova, M., \& Safavian, M. (2009) Mortgage registration and foreclosure around the globe: Evidence from 42 countries. Housing Finance International, pp. 19-29.

Castillo, J. D. R., \& Laviada, J. G. (1999). Infonavit and the development of housing for low-income workers in Mexico. Housing Finance International, 14(4), 42-47.

Chan, Y.-S., \& Kanatas, G. (1985). Asymmetric valuations and the role of collateral in loan agreements. Journal of Money, Credit and Banking, 17(1), 84-95.

Chan, Y.-S., \& Thakor, A. V. (1987). Collateral and competitive equilibria with moral hazard and private information. The Journal of Finance, 42(2), 345-363.

Chiquier, L., Hassler, O., \& Lea, M. (2004). Mortgage securities in emerging markets financial sector operations and policy department (Vol. 3370). Working paper 3370, World Bank Policy Research, August 2004.

Chiquier, L., \& Lea, M. (2009). Housing finance policy in emerging markets. Washington, DC: World Bank.

Collins, J., \& Cooke, D. K. (2011). Creative role models, personality and performance. Journal of Management Development, 32(4), 336-350.

De Soto, H. (2001). The mystery of capital. Finance and Development, 38(1), 29-33.

Derban, W. K., Derban, D. K., Ibrahim, G., \& Rufasha, K. (2002). Micro finance for housing for low/moderate-income households in Ghana. In Presentation at the conference on housing and urban development for low-income groups in Sub-Saharan Africa, pp 22-26.

Dickerson, A. M. (2009). The myth of home ownership and why home ownership is not always a good thing. Indiana Law Journal, 84, 189.

Donkor-Hyiaman, K. A., \& Owusu-Manu, D. (2016). Another look at housing finance in Africa: The anatomy of pension asset-backed housing financing. International Journal of Housing Markets and Analysis, 9(1), 20-46.

Drucker, P. F. (1998) The discipline of innovation. Harvard Business Review. Reprint number 98604. November-December 1998. https://hbr.org/2002/08/the-discipline-of-innovation. Accessed September 2016. 
Edwards, S. (1995). Why are saving rates so different across countries? An international comparative analysis. NBER working paper no. 5097. http://www.nber.org/papers/w5097.pdf. Accessed November 2016.

Egan, K. (2005). An imaginative approach to teaching. San Francisco, CA: Jossey-Bass.

Engelen, E., Erturk, I., Froud, J., Leaver, A., \& Williams, K. (2008). Financial innovation: Frame, conjuncture and bricolage. Centre for Research on Socio-Cultural Change (CRESC). Working paper no. 59. University of Manchester.

Fagerberg, J. (2003). Innovation: A guide to the literature. Centre for Technology, Innovation and Culture, University of Oslo. http://in3.dem.ist.utl.pt/mscdesign/03ed/files/lec_1_01.pdf. Accessed September 2016.

Ferguson, J. (1999). Expectations of modernity: Myths and meanings of urban life on the Zambian Copperbelt (Vol. 57). Oakland: University of California Press.

Gevorgyan, K., Hirche, S. W., \& Entwicklungsbank, K. (2006). Promoting housing finance market development in Armenia. Housing Finance International, 21(2), 19.

Gramlich, E. M. (2007). Subprime mortgages: America's latest boom and bust. Washington: The Urban Institute.

Guttentag, J. (2004). The mortgage encyclopedia. New York: McGraw-Hill Companies, Inc.

Hamilton, R., Jenkinson, N., \& Penalver, A. (2007). Innovation and integration in financial markets and the implications for financial stability. In Structure and resilience of the financial system, proceedings of a conference, Reserve Bank of Australia, Sydney, pp. 226-250.

Hart, O., \& Moore, J. (1994). A theory of debt based on the inalienability of human capital. The Quarterly Journal of Economics, 109(4), 841-879.

Hart, O., \& Moore, J. (1998). Default and renegotiation: A dynamic model of debt. The Quarterly Journal of Economics, 113(1), 1-41.

Herbert, C. E., Belsky, E. S., \& DuBroff, N. (2012). The state of Mexico's housing: Recent progress and continued challenges. Cambridge: Joint Center for Housing Studies, Harvard University.

Holzmann, R., Hinz, R. P., Von Gersdorff, H., Gill, I., Impavido, G., \& Musalem, A. R. (2005). Old-age income support in the twenty-first century: An international perspective on pension systems and reform. Washington, DC: World Bank.

International Monetary Fund. (2007). Mexico: Financial sector assessment program update-technical note-housing finance. IMF Country Report No. 07/162. https://www.imf.org/external/pubs/ft/ scr/2007/cr07162.pdf. Accessed September 2016.

Jaffee, D. M. (1999). Strategies to develop mortgage markets in transition economies. Washington: The World Bank.

Jappelli, T., \& Pagano, M. (1993). Information sharing in credit markets. Journal of Finance, 43, $1693-1718$.

Johnson, S., \& Rogaly, B. (1997). Microfinance and poverty reduction. Nairobi: Oxfam.

Jones, G., \& Datta, K. (2002). Housing and finance in developing countries: Invisible issues on research and policy agendas. Habitat International, 25, 333-357.

Karley, N. K. (2002). Alternative options to mortgages in Ghana. Housing Finance International, 17(1), 26-30.

Karley, N. K. (2003). Challenges in mortgage lending for the underserved in South Africa. Housing Finance International, 18(1), 27-33.

Krainer, J., \& Laderman, E. (2011). Prepayment and delinquency in the mortgage crisis period. Federal Reserve Bank of San Francisco working paper series. http://www.frbsf.org/economic-research/files/ wp11-25bk.pdf. Accessed October 2016.

Lerner, J., \& Tufano, P. (2011). The consequences of financial innovation: A counterfactual research agenda. Annual Review of Financial Economics, 3, 6.

Lipsky, J. (2007). International financial markets-Stability and transparency in the 21st century keynote speech by John Lipsky, first deputy managing director. International Monetary Fund at the Social Democratic Party Caucus Berlin, June 20, 2007. http://www.imf.org/external/np/speeches/2007/06200 7.htm. Accessed October 2016.

Mathema, A. S. (1999). Housing and land markets in Kathmandu, Nepal. Cambridge, MA: Department of Urban Studies and Planning Massachusetts Institute of Technology.

McCarthy, D., Mitchell, O. S., \& Piggott, J. (2002). Asset rich and cash poor: Retirement provision and housing policy in Singapore. Journal of Pension Economics \& Finance, 1(3), 197-222.

Merrett, S., \& Russell, K. (1994). Non-conventional finance for self-help housing. Habitat International, $18(2), 57-69$.

Merton, R. C. (1995). A functional perspective of financial intermediation. Financial Management, 24(2), $23-41$. 
Miller, M. H. (1986). Financial innovation: The last twenty years and the next. Journal of Financial and Quantitative Analysis, 21(4), 459-471.

Mitlin, D. (1997). Building with credit: Housing finance for low-income households. Third World Planning Review, 19(1), 21.

Morandé, F. (1998). Savings in Chile: What went right? Journal of Development Economics, 57(1), 201-228.

Mutero, J., Bishota, M., Kalema, W., \& Kayiira, D. (2010). Mobilising pension assets for housing finance needs in Africa-Experiences and prospects in East Africa. Centre for Affordable Housing Finance, FinMark Trust. http://www.housingfinanceafrica.org/wp-content/uploads/2010/12/Pensi on_assets_and_housing_Eastern_Africa.pdf. Accessed October 2016.

OECD. (2005). Oslo manual, guidelines for collecting and interpreting innovation data (3rd ed., pp. 47-52). Paris: OECD Publishing.

Ollennu, N. A. (1962). Principles of customary land law in Ghana. Law in Africa (Vol. 2). London: Sweet and Maxwell.

O'Reilly, J. (1996). Labour market adjustment through part-time work. In G. Schmid, J. O'Reilly \& K. Schömann (Eds.), International handbook of labour market policy and evaluation (pp. 566-593). Cheltenham: Edward Elgar.

O'Sullivan, A., \& Sheffrin, S. M. (2003). Economics: Principles in action. Pearson Prentice Hall: Upper Saddle River, NJ.

Pagano, M., \& Jappelli, T. (1993). Information sharing in credit markets. The Journal of Finance, 48(5), $1693-1718$.

Patel, S. (1999). Interpreting gender and housing finance in community practice: The SPARC, Mahila Milan and NSDF experience. Housing and Finance in Developing Countries, pp 157-168.

Paulson, J. A., \& McAndrews, J. (1998). Financial services for the urban poor South Africa. Washington: Banco Mundial.

Phang, S-Y. (2007). The Singapore model of housing and the welfare state. Housing and the New Welfare State: Perspectives from East Asia and Europe. https://ink.library.smu.edu.sg/cgi/viewconten t.cgi? article $=1595 \&$ context=soe_research. Accessed: October 2016.

Rakodi, C. (1995). Housing finance for lower income urban households in Zimbabwe. Housing Studies, 10(2), 199-227.

Ramadani, V., \& Gerguri, S. (2010). Innovation: Principles and strategies [online]. MPRA paper no. 22267. http://mpra.ub.uni-muenchen.de/22267/. Accessed October 2016.

Reddy, P. S., \& Brijlal, P. (1992). The role of pension funds in housing finance: The South African scenario. Development Southern Africa, 9(2), 187-198.

Renaud, B. (1987). Another look at housing finance in developing countries. Cities, 4(1), 28-34.

Renaud, B. M. (2008). Mortgage finance in emerging markets: Constraints and feasible development paths. Mortgage Markets Worldwide, pp 253-288.

Schrieder, G., \& Heidhues, F. (1995). Reaching the poor through financial innovations. Quarterly Journal of International Agriculture, 34(2), 132-148.

Short, R., King, J., Musa, O., Hobden, T., \& Sing, L. (2009). Mobilizing pension assets for housing needs-Experiences in Southern Africa. A report prepared for the FinMark Trust. http://www.housi ngfinanceafrica.org/document/mobilizing-pension-assets-for-housing-needs---experiences-in-south ern-africa/. Accessed October 2016.

Siembieda, W. J., \& López Moreno, E. (1999). From commercial banking systems to non-commercial banking systems in Mexico. In Housing and finance in developing countries (pp. 75-88). New York: Routledge.

Sing, L. (2009). Pension-secured loans: Facilitating access to housing in South Africa. FinMark Trust. A Report prepared for the FinMark Trust. http://www.housingfinanceafrica.org/wp-content/uploa ds/2009/06/Pension_secured_loans.pdf. Accessed October 2016.

Stiglitz, J., \& Weiss, A. (1981). Credit rationing in markets with imperfect information. American Economic Review, 71, 393-410.

Teye, K. J., Teye, I., \& Asiedu, M. O. (2015). Financing housing in Ghana: Challenges to the development of formal mortgage system. Journal of Housing and the Built Environment, 30(1), 1-16.

Tomlinson, M. (2007). The development of a low-income housing finance sector in South Africa: Have we finally found a way forward? Habitat International, 31, 77-86.

Toulmin, C. (2008). Securing land and property rights in Sub-Saharan Africa: The role of local institutions. Land Use Policy, 26, 10-19.

Townsend, R. M. (1979). Optimal contracts and competitive markets with costly state verification. Journal of Economic theory, 21(2), 265-293.

Tufano, P. (2003). Financial innovation. Handbook of the Economics of Finance, 1, 307-335. 
Turner, J. F. C. (1976). Housing by people. London: Marion Boyars Publishers.

UN-Habitat. (2010). Housing finance mechanisms in Brazil. UN-Habitat: Kenya. http://unhabitat.org/ books/housing-finance-mechanisms-in-brazil/housing-finance-mechanisms-in-brazil/. Accessed October 2016.

UN-Habitat. (2012). Ghana housing profile. UN-Habitat: Kenya. http://mirror.unhabitat.org/pmss/listI temDetails.aspx?publicationID=3258. Accessed October 2016.

United Nations Children's Fund (UNICEF). (2014). UNICEF Annual Report 2014. http://www.unicef.org/ publications/index_82455.html. Accessed November 2016.

United Nations, Department of Economic and Social Affairs, Population Division. (2017). World Mortality 2017 - Data Booklet (ST/ESA/SER.A/412).

United Nations Development Programme (UNDP). (2014). Human Development Report. New York: UNDP.

Ward, P. M., \& Macoloo, G. C. (1992). Articulation theory and self-help housing practice in the 1990s. International Journal of Urban and Regional Research, 16(1), 60-80.

Zhou, J. (2003). When the presence of creative coworkers is related to creativity: Role of supervisor close monitoring, developmental feedback, and creative personality. Journal of Applied Psychology, 88(3), 413-422.

\section{Statutory Documents}

Home Mortgage Finance Act, 2008 (770). Ghana

National Pension Act, 2008 (Act 766). Ghana.

Pension Fund Act, 1956 (Act 24). South Africa.

Publisher's Note Springer Nature remains neutral with regard to jurisdictional claims in published maps and institutional affiliations.

\section{Affiliations}

\section{K. A. Donkor-Hyiaman ${ }^{1}$ - E. A. Pärn² · D. Owusu-Manu ${ }^{3}$ D. J. Edwards² ${ }^{2}$. C. Aigbavboa ${ }^{4}$}

K. A. Donkor-Hyiaman

kwakuhyiaman@gmail.com

E. A. Pärn

erikaparn@gmail.com

D. Owusu-Manu

d.owusumanu@gmail.com

C. Aigbavboa

clintonaigbavboa@gmail.com

1 Department of Land Economy, Kwame Nkrumah University of Science and Technology, Kumasi, Ghana

2 School of Engineering and the Built Environment, Birmingham City University, Birmingham, UK

3 Construction Management and Economics, Department of Building Technology, Kwame Nkrumah University of Science and Technology, Kumasi, Ghana

4 Faculty of Engineering and the Built Environment, University of Johannesburg, Johannesburg, South Africa 